Publisher homepage: www.universepg.com, ISSN: 2707-4668 (Online) \& 2707-465X (Print) https://doi.org/10.34104/ajssls.020.071075

Asian Journal of Social Sciences and Legal Studies Journal homepage: www.universepg.com/journal/ajssls

\title{
A Judicial Exploration of Portia in The Merchant of Venice: A Critical Study
}

\author{
Muhammed Asgor Hossain ${ }^{1}$ and Md. Shaon Akter ${ }^{2} *$ \\ ${ }^{1}$ Department of English, Islamic University, Kushtia, Bangladesh; and ${ }^{2}$ Department of English, Khwaja Yunus Ali \\ University, Sirajgonj, Bangladesh. \\ *Correspondence: shekhshaon1989@gmail.com (Md. Shaon Akter, Lecturer, Department of English, Khwaja Yunus Ali \\ University, Sirajgonj, Bangladesh).
}

\begin{abstract}
The term "Judicial" stands for an idea relating to the administration of justice or a phenomenon appropriate to the law or judgement. In the present study, we have an interesting character Portia in William Shakespeare's The Merchant of Venice who disguises herself as the judiciary personality to explore a judiciary case in the court of Venice. She submitted her identity before the judge as a legal pleader appointed by the Duke of Venice to run the case between Antonio and Shylock. Shylock gets ready to cut one pound of flesh from the heart of Antonio according to the contract between them. Antonio is quite disappointed finding no other alternatives to rescue his life. The audience also gets disheartened that there is no way left for Antonio's life and this trial will finally come to an end. In that crucial moment of utter helplessness, Portia arrives as a heavenly savior for Antonio to rescue him as a competent lawyer. So in this study, it shows Portia's judicial portrait and as a successful female lawyer.
\end{abstract}

Keywords: Judicial exploration, The Merchant of Venice, Critical study, Shylock's, and Portia.

\section{INTRODUCTION}

In The Merchant of Venice it seems that Portia disguises as Balthasar, a man of Law in order to travel to Venice and to enter the courtroom as a lawyer. In Shakespeare's time, women were considered inferior to men. They were not allowed to exercise freedom. By means of disguise, Shakespeare's female characters experienced some power and freedom that a woman could usually not enjoy in a family. She has proved that she is the only character who has necessary strength to stop Shylock's unfair business. Her intervention in the court allows the audience to witness her extraordinary wit and power to deal with Shylock's and Antonio's sensitive issue. Antonio's life was at stake as he has promised to pay a huge amount of loan three thousand ducats to Shylock which was needed for his friend Bassanio to win the heart of his indented Portia. At that time Antonio's money was invested in the fleets which were in the sea. So, he went to a Jewish usurer Shylock to borrow money from him with a dreadful contract that if he failed to pay the loan within three months, Shylock could cut off one pound of flesh from his heart. Unfortunately, his two ships were wrecked in the sea by the storm. So, he could not pay the money in due 
time. Shylock was seeking for this type of opportunity to take revenge upon Antonio as he was a Christian and did not like Shylock. Lastly, he got the chance and was taking preparation to fulfill his desire.

Antonio sent this message to his friend Bassanio who was taking preparation for marriage with Portia. When Bassanio heard this ill news, he let Portia know of it. At this stage, Portia hit upon a plan to disguise herself as a Venetian lawyer to face the crucial case hiding her own identity. She arranged everything according to her plan and finally arrived at the court in the appointed day. In course of the trial, she came out successful to defeat Shylock through her wit. Here we shall prove that even a girl has the ability to prove herself as a successful lawyer. The study was undertaken for the following objectives: To show the judicial of Portia, and to prove her as a successful lawyer.

\section{Review of Literature}

Portia is not only a courageous lady in the play but also a typical character of Shakespeare from the perspective of feministic approach (Akter et al., 2020). Shakespeare was very conscious about his contemporary society. Women were very suppressed and oppressed because of the patriarchy in the contemporary society of Shakespeare. There are a lot of evidences of treating women negatively in the age of Shakespeare. He depicted the contemporary life style, society, religion, politics, love and death very Skillfully. A profound philosophy about life has been reflected in the writing of Shakespeare along with the social atmosphere. In Shakespeare we notice the conflict between the fathers and the daughters to establish the rights of the daughters. In Portia, we see her as an efficient lawyer in one hand and in the other hand, Shakespeare has established the female rights in the society through her. He has attempted to prove that a female character is capable enough to explore everywhere along with the judicial sector.

In The Merchant of Venice, Portia is one of the most influential characters of Shakespeare. Here we see her as a submissive and obedient daughter to her father.
Her father tied her luck with a casket scene. That means Portia could marry only that suitor who would choose the right casket in which Portia's portrait was hidden among the three-gold, silver and lead. But if any suitor failed to choose the right casket, he would leave immediately and would never be able to woo another woman ever again. However, the Prince of Morocco, and the Prince of Arragon failed to choose the right casket but Bassanio (Antonio's friend) chose the right one and he won Portia. Actually, this was a difficult job for Portia regarding her marriage. This was a patriarchal oppression towards the daughters. Yet, Portia remained obedient with father's decision though some critics have commented it as a burial for living Portia out of fun. For example, Leslie A Fielder said: Portia is "locked in a coffin, where she lies, as if wrapped in lead, until he (suitor) revives her'" (Fielder, Leslie A, 1986). Hilsky believes that woman's disobedience to her husband or father was not regarded just as a private offense, but as a violation of divine order. Besides, Shakespeare belonged to the age of Elizabeth and there is a famous speech of Queen Elizabeth: "I know I have the body of a weak and feeble woman, but I have the heart and stomach of a king, and of a king of England too,..." (Henry VIII Cross Stitch, 2020).

This trend is noticed in the daughters of Shakespeare's plays.. But they had to struggle a lot to come out successful. Juliet Dusinberre points out that "in Elizabethan and Jacobean times, freedom of conscience for women was still a new concept (Dusinberre, Juliet, 1975). It is exactly at this point that Shakespeare tried to introduce Portia to prove herself as a competent girl. Because of her intelligence and wit she climbed up to the peak of Shakespeare's heroines. She disguised herself as a lawyer and went to Venice and proved her worth in winning the case.

Bassanio and Portia were taking preparation for marriage, but at that time Bassanio heard that Antonio failed to pay the due to Shylock in time and Shylock was getting ready to cut off one pound of flesh according to the contract. Being informed by Bassanio, Portia extended her helping hand to 
Antonio. Disguising herself as a young smart lawyer, she pretended to be a man of law, and entered the court of Venice where the prosecution was to be started. In this context, the comment of Jardine is mentionable.: "Portia is quite a self-assured woman who is aware of men's usual tricks and who thinks that she is intelligent enough to outsmart the men at court" (Jardine, Lisa, 1996). The climax of the story is noticed in the court of the Duke of Venice. Bassanio offered Shylock six thousand ducats in lieu of three thousand. But Shylock wanted to take one pound of flesh only nothing else. Portia gave her identity as Balthazar, a doctor of law, and she gave the Duke a letter of recommendation from the reputed lawyer Bellerio. Portia, first of all, requested Shylock to show mercy explaining that showing mercy is beneficial for the person who shows it as well as for the person who receives it:

\section{Portia: It is twice blest;}

It blesseth him that gives, and him that takes. (IV.1 l.183-184)

Yet she also revealed her very witty mind because she is not only able to show feelings but she mainly uses clever reasoning to convince Shylock. In fact, she first pointed out that showing mercy would improve his reputation and secondly it would even elevate him to a God-like being:

Portia: It becomes

The thronèd monarch better than his crown.

His sceptre shows the force of temporal power,

The attribute to awe and majesty,

Wherein doth sit the dread and fear of kings;

But mercy is above this sceptred sway.

It is enthronèd in the hearts of kings;

It is an attribute to God himself,

And earthly power doth then show likest God's
When mercy seasons justice. (IV.1 1.185-194)

But Shylock refuses everything and became adamant to take the flesh. Portia also warned him that not showing any mercy may eventually lead to his own damnation:

Portia: That in the course of justice none of us

Should see salvation. We do pray for mercy,

And that some prayer doth teach us all to render

The deeds of mercy. (IV.1 l.196-199)

Portia wants to save Antonio's life. This is why, she tries to convince Shylock about the matter very smartly with legal arguments. The court permitted Shylock to cut off one pound of flesh from any part of Antonio's body. At that point, Portia came forward to warn him that the contract allowed him one pound of flesh only not any single drop of blood. If Shylock were to shed any drop of blood, his lands and goods would be forfeited according to the Venetian laws. She also told Shylock that he must cut just one pound of flesh, no more or less than that. Shylock found no ways to execute his contract. So he agreed to take six thousand ducats for the defaulted contract. But Portia denied it as Shylock refused it in the open court. She also declared that Shylock's property would be forfeited as he initiated to kill a man. Half of his property would go to the Government and half to Antonio. Portia is well informed about what she should do to defend the accused. It is very clear in her speech:

Portia: This bond doth give thee here no jot of blood.

The words expressly are 'a pound of flesh'.

Take then thy bond. Take thou thy pound of flesh.

But in the cutting it, if thou dost shed

One drop of Christian blood, thy lands and goods

Are by the laws of Venice confiscate

Unto the state of Venice. (IV.1 1.303-309) 
These words give the audience the impression that Portia will eventually be able to outsmart Shylock because it will be impossible for him to cut a pound of flesh out of Antonio without starting to bleed. She definitely beats. Her cleverness is also found when she expresses the following lines:

Portia: It is enacted in the laws of Venice,

If it be proved against an alien

That by direct or indirect attempts

He seek the life of any citizen,

The party 'gainst the which he doth contrive

Shall seize one half his goods; the other half

Comes to the privy coffer of the state,

And the offender's life lies in the mercy

Of the Duke only, 'gainst all other voice -

In which predicament I say thou stand'st,

For it appears by manifest proceeding

That indirectly, and directly too,

Thou hast contrived against the very life

Of the defendant, and thou hast incurred

The danger formerly by me rehearsed.

Down, therefore, and beg mercy of the Duke. (IV.1 1.345-360)

The fact that Portia makes Shylock lose all his money and forces him to convert to Christianity hurts him significantly. At this instant Portia experiences a real success because she makes Shylock suffer badly and simultaneously she manages to save. Antonio's life. By this great and auspicious job, Portia managed to alter her entire personality. This success proves that she is still superior to her male counterparts.

T. Duff Barnett argues that Portia "breaks through the law by a quibble, which strikes us as being rather clever, coming from one we know to be a woman" (Linda Rozmovits, 1995). G. K. Chesterton says: The whole point of her position is that she is a heroic and magnanimous fraud. She has not taken up the legal profession, or any profession; she has not sought that public duty, or any public duty. Her action, from first to last, is wholly and entirely private (Chesterton, G. $\mathrm{K}, 1923)$. It is also worth mentioning the comment of Clara Claiborne Park: It is not surprising that Portia alone among Shakespeare's heroines is allowed to confront a man over matters outside the traditional sphere of a woman and to win, not unlike Elizabeth (Park, Clara Claiborne, 1980). Jameson describes Portia as a woman of intelligence. She sees a woman's intellect as being magnified by "sympathies and moral qualities" that, in her opinion, men don't possess in the same degree as women (Jameson, Anna Brownell, 2012).

\section{CONCLUSION:}

In The Merchant of Venice, the audience witnessed Portia's extraordinary wit. It may be pointed out that an Elizabethan woman talked in such a manner as if she exactly knew how the law of her society worked although women usually had no access to law at all. Portia's ease in dealing with matters of law indicates her immense intelligence and good education. In this context, we can mention the comment of Stretton: In Elizabethan times, pleading by women, was not permitted in any legal setting. Women could be litigants but they could not be judges, jurors or lawyers. Along with heretics, excommunicants and criminals, no woman could plead on behalf of someone else before a judge. Yet, it has been possible because of Portia's immense wits and absolute power.

\section{ACKNOWLEDGEMENT:}

We would like to thank those who work on this topic of the research study to complete successfully.

\section{CONFLICT OF INTERESTS:}

The authors declared there are no conflict of interest to publish the present research study. 


\section{REFERENCES:}

1. Akter MS, Hossain MA, Akter F, and Zalil MA. (2019). A Feministic Approach to Nora of Henric Ibsen's A Doll's House, Br. J. Arts Humanit., 1(5), 28-34.

https://doi.org/10.34104/bjah.019.28034

2. Chesterton, G. K. (1923). Shakespeare and the Legal lady. London: Methuen. p.48-49.

3. Dusinberre, Juliet. (1975). Shakespeare and the Nature of Women. London: Macmillan. p.93.

https://doi.org/10.1007/978-1-349-24531-4

4. Fielder, Leslie A. (1986). These Be the Christian Husbands in William Shakespeare's The Merchant of Venice. New York: Chelsea House Publishers. p.75

https://scholar.google.com/scholar_lookup?hl=e n\&publication year $=1972$ \&pages $=63-89$ \&auth or $=+$ Fiedler\%2C + L.author $=+$ H. + Bloom. $\&$ title $=$ These+be+the+Christian+husbands

5. Henry VIII Cross Stitch, (2020). Lockdown sewing journey to sew Henry VIII and his Six Wives. Online available link http://tudorblogger.wordpress.com/
6. Jameson, Anna Brownell, (2012). Characteristics of Women, Moral, Poetical and Historical, Volume 1 Paperback -August 31, 2012, London: Saunders \& Otley. p.75. https://www.amazon.com/Characteristics-Wom en-Moral-Poetical-Historical/dp/B00A27M3BA

7. Jardine, Lisa. (1996) Reading Shakespeare Historically. New York: Routledge. $1^{\text {st }}$ Edition, eBook ISBN9780203993774. https://doi.org/10.4324/9780203993774

8. Linda Rozmovits, (1995). New woman meets Shakespeare woman: the struggle over the figure of Portia in England in the late nineteenth and early twentieth century's, Women's History Review, 4(4), 441-464. https://doi.org/10.1080/09612029500200094

9. Park, Clara Claiborne, (1980). "As We Like It: How a Girl Can Be Smart and Still Popular.", The Woman's Part: Feminist Criticism of Shakespeare. eds. Carolyn Ruth Swift Lenz, Gayle Greene, and Carol Thomas Neely.100-116. Urbana: University of Illinois Press. p.283.

https://www.worldcat.org/title/womans-partfeminist-criticism-of-shakespeare/oclc/5831018

Citation: Hossain MA. and Akter MS. (2020). A judicial exploration of portia in The Merchant of Venice: a critical study, Asian J. Soc. Sci. Leg. Stud., 2(4), 71-75. https://doi.org/10.34104/ajssls.020.071075@ @ 